\title{
10 Encounters with Alterity: Romani on the Contem- porary Italian Stage
}

When the first written records about the Roma ${ }^{163}$ by non-Roma started to appear in Western Europe in the fifteenth century, the use of derogatory language showed attempts by opponents to dominate a group with puzzling and unsettling ethnocultural traits, primarily concerning their appearance and unconventional way of life (Toninato, 2014, p. 7). These narratives, according to Toninato, are "written ... with the aim of constructing the 'Gypsies' difference in negative terms ... deliberately marking out their behaviour as deviant and dangerous. Such narratives have played a fundamental role in defining the Gypsy as the 'ultimate alien' (Lucassen, Willems, \& Cottaar, 1998, p. 61) in European society” (Toninato, 2014, pp. 7-8).

In Europe today, the portrayal of the Roma as thieves and beggars in local and national media is still highly commonplace. In Italy, where they are commonly known as "zingari" [gypsies], a pre-election campaign by the Centre-Right in 2018 proposed to dismantle Roma camps as a national priority, along with tackling the refugee crisis, in order to win people's consent and votes ${ }^{164}$.

Contemporary theatre practitioners, however, have created counter-narratives, with the aim of telling different stories based on direct contact with members of Romani communities. The outcome, presented in the form of various stage productions, denotes a cultural interweaving that challenges popular views of Romani identity.

With this in mind, this chapter focuses on four contemporary Italian playwrights, namely Daniele Lamuraglia (Florence), Fiorenza Menni and Andrea Mochi Sismondi (Bologna), and Pino Petruzzelli (Genoa). Although their productions vary considerably, what these theatre practitioners have in common is an approach to 'the different other' based on their personal knowledge of the Roma, which communicates the need to give a voice to those excluded from society in theatrical discourse.

This chapter is divided into two parts. The first, theoretical section is centred on the transcultural concept theorized by the Cuban anthropologist Fernando Ortiz. According to Ortiz, the acceptance that cultures within a colonial environment influence one another through a process of losses and acquisitions helps to establish a greater balance in the relationship between the colonizer and the colonized. In this chapter I will explore how Ortiz's theory can be adopted in other contexts, within

163 I will employ the term "Roma” (pl. n.), “Rom” (m.s. n.), “Romni” (f.s. n.) “Romani” (adj.) throughout, while the term Gypsy will be employed when it is used by non-Roma or in citations.

164 Articles on the Italian press abound. See e.g. Matteo Salvini, leader of the North League party, promises to destroy all the Romani camps and to fly all the Romani people out of Italy (Rame, 2018). 
this essay-collection's focus of transcultural life-worlds. In the first part I will also consider the dichotomy between centre and margin (or periphery), which plays an important role in both the research undertaken by theatre practitioners and the methodology concerning “difference", when they seek to put on stage Romani identity. In the second part of the chapter the theoretical concepts discussed will be applied to the following theatrical productions, Lamuraglia's Cristo Gitano (2003), Telerom and Zingarità (2004); Comune spazio problematico (2008) and Open Option by Menni and Mochi Sismondi; and, finally, Non chiamarmi zingaro (2008) by Petruzzelli. First, a discussion of the directors' approaches (or, in the case of Petruzzelli, the narrator) will provide an understanding of transcultural theory, as applied to what can be considered a preliminary phase of the theatrical production, during which the non-Roma and the Roma familiarize with each other through dialogue and extended periods of time spent together, primarily within a non-Roma family and/or community. This will be followed by an analysis of the performances themselves, primarily as cultural representations, which can shed light on the majority's perception of Romani people. These performances offer an opportunity to appreciate their mutual similarities and differences and reflect on how transcultural approaches attempt to change the centre/ periphery dichotomy in the relationship between non-Roma and Roma.

\subsection{Transcultural Perspectives from the Periphery}

"Transculturation" is a term coined in 1947 by the Cuban anthropologist Fernando Ortiz to indicate the transformative process undergone by a society in the acquisition of "foreign" cultural resources. More specifically, in Cuban society, it describes the interplay of influences between Africans and Latin Americans.

Transculturation was originally intended to replace various expressions in use such as "cultural exchange", "acculturation" "diffusion", "migration or osmosis of culture", and other terms that Ortiz considered inadequate (1947, p. ix). The term took into consideration the possibility that both foreign and indigenous peoples are modified by being in each other's presence. This means that change not only occurs as a process of acculturation undergone by foreigners settling in a different culture, but that cultural differences influence all the parties involved. This represents what Ortiz calls "... an exchange between two cultures, both of them active, both contributing their share, and both co-operating to bring about a new reality of civilization" (Ortiz, 1947, p. xi).

The concept of transculturation can be compared to the poetics of creolization, as theorized by the Caribbean philosopher from Martinique, Èdouard Glissant (1996), who saw the emergence of the Creole language as a fusion between French and Caribbean languages in a colonial context. The Creole language became, for Glissant, a metaphor for the emergence and transformation of cultures and identities. 
When transferring Ortiz's concept of transculturation into a different socio-cultural context, one must take into consideration that it originated in a colonial milieu framed around the dominant and the dominated. Interestingly, although its transfer to "our" contemporary "Western" world requires us to consider the absence of a colonial relationship between foreign and indigenous parties, it has been observed that dominant attitudes towards "the other", whether immigrants, refugees, or Romani in the "Western" world, often perpetuate or recreate the binary opposition of dominant and dominated which was typical of colonial societies ${ }^{165}$. However, we should also highlight the differences with its colonial context, as in the case of creolization, which has been described as "a process of contention ... deeply embedded in the history of enslavement, racial terror and subaltern survival in the Caribbean, in conflict, trauma, rupture and the violence of uprooting” (Ahmed et al., 2003, p. 281).

In recent usage, Ortiz's transculturation has here become a term which can be adopted to indicate different forms of cultural mixing. As Diana Taylor says:

The importance of stressing the liberating potential of the theory of transculturation is that it is one of the few theories that allows an opening to the impasse usually set up in relation to minority theories ... rather than being oppositional or strictly dialectical, it circulates. It is applicable to other dominated cultures and, unlike dominant theories, it highlights their vitality rather than their indebtedness to First World culture. Potentially, the hope might be that by engaging the many, previously marginalized others, these cultures may be able to decenter (not replace) the hegemonic. (Taylor, 1991, pp. 101-102)

The importance of this transcultural theory, therefore, lies in its potential to deconstruct the binary oppositions between centre and periphery and dominant and dominated, by including in society marginalized, peripheral voices that are usually unheard.

The outcome of transculturation is unpredictable; it is a process that touches the established and introduces new elements that can shape new realities (Glissant, 1996, p. xii).

Yet one wonders to what extent the unequal power relations in the "Western" world can ever lead to a cultural exchange where even the dominant agrees to undergo a partial disculturation, a process through which parts of the culture of origin are lost, and a process of partial acculturation, when elements of another culture are acquired, thus generating new cultural identities (Taylor, 1991, p. 93).

As in other contexts of unequal relationships, for example in the academic fields of postcolonial and gender studies, the question of "voice”, and more specifically

165 Postcolonial studies focus on the cultural legacy of colonialism and imperialism, for example Ania Loomba, Colonialism/Postcolonialism (2005); Robert J. C. Young, Postcolonialism: an historical introduction (2001) and Bill Ashcroft and Gareth Griffiths, Post-colonial studies, the key concepts (2007). 
the suppression of ethnic minority voices in the public sphere, is of central concern to a theatre interested in differences. As De Martino writes, "[i]n a global world that is developing an ever more diverse fabric - both in linguistic and cultural terms theatre cannot but acknowledge the presence of a multitude of voices that feel entitled to speak up"166 (De Martino et al., 2013, p. 1).

In their still very relevant essay that maps out theatrical praxis in the presence of more than one culture, Jacqueline Lo and Helen Gilbert present a range of subdivisions to describe the different degrees of involvement with cultural differences on stage. Thus, "cross-cultural theatre" denotes the umbrella-term for the presence of and encounter with different "cultural fragments" that involve some form of negotiation. For Lo and Gilbert, the term "transcultural" has been seen as a sub-genre of "Intercultural theatre", a term which indicates "intentional encounters between cultures and performing traditions” (Lo \& Gilbert, 2002, p. 37). Taking intentionality as a key component of the transcultural approach, a theatre director or practitioner will use cultures and traditions to identify similarities rather than differences (Pavis, 1996, p. 6). However, this does not mean that differences are erased. Theatre, based on a relationship between the director, actors, and audience, can present a particularly fertile soil for artistic métissage which is inclusive of multilingualism and multiculturalism. More specifically, within the context of this study, by placing Romani actors on stage, or by putting Romani issues at the centre of a performance, this type of theatre deliberately breaks away from majority representations, constructing emancipatory life-worlds of different experiences and new realities.

The dramatists discussed in this chapter approach "difference" in ways that can dismantle the static quality of the centre/periphery dichotomy. Their decision to meet the Roma in their communities allows them to learn from their ways of life and to reflect on themselves as members of a different community. This can be seen as akin to the work of the contemporary ethnographer, whose research requires reflection on the impact of one's own perspective on their work, and how in turn their perspectives will impact on others when they share their work. Like a contemporary ethnographer, these dramatists engage in conversation with the research-participants rather than interviewing them, and they partake in their life during the time they spend with them ${ }^{167}$. To a greater or lesser extent, the self-reflexive quality of these playwrights' works has influenced the staged works under analysis in this chapter,

166 On the question of 'giving a voice to disadvantaged people' it is worth mentioning Augusto Boal, a theatre practitioner from Brazil who, in the 1960s, founded the Theatre of the Oppressed. This was devised to educate people from poor communities and enable them to find a solution to their ongoing problems. In Italy, Annet Henneman, the director of Hidden Theatre (Teatro di Nascosto), based in Tuscany, has been putting refugees and the suffering of people in Middle Eastern conflict zones, at the center of her theatrical events.

167 On the subject of reflexive ethnography, see for example, Charlotte Aull Davies, Reflexive Ethnography. A guide to researching Selves and Others (2002). 
which together present three different levels of representation of the Roma people. Lamuraglia places Romani culture, language and actors at centre stage, where they can present their own culture and voice their opinions of the way they are popularly represented in Italy. Menni and Mochi Sismondi, on the other hand, adopt a more anthropological approach, that aims to include Romani opinions in contemporary global, sociological and political issues, choosing to be a mouthpiece for the Romani and also working with them on stage. Finally, Petruzzelli in the role of narrator uses his voice to describe the racial discrimination and subsequent pain inflicted to the Roma in ordinary life, offering an emotive dimension which is largely absent from media coverage on the Romani.

\subsection{The Roma Visible on Stage: Lamuraglia and the Rom Trilogy}

The founder of 'Teatro del Legame' in Florence, Lamuraglia is the first playwright and theatre director to bring the Roma on stage with three plays: Cristo Gitano ${ }^{168}$ (2003), Telerom and Zingarità (2004) ${ }^{169}$. His intention, in his own words, to "dare voce e portare alla luce quelle verità che sono oscurate e non possiedono altri spazi per mostrarsi" ${ }^{170}$ (Teatro del Legame, n.d.) will be apparent from his theatrical choices.

The first play, Cristo Gitano, is the modern interpretation of an ancient myth which was previously mentioned by the Italian writer Antonio Tabucchi. It narrates the story of a Gypsy Christ born every three generations and crucified by his gypsy community ${ }^{171}$. In the story, a foreigner recruits the four Romani to act as disciples in a play about the passion of Christ. In exchange, they will receive a sum of money that will substantially improve their lives. The foreign man is named [the] Cristo Gitano and the four Romani are given the names of some of the biblical apostles: Giacomo, Giovanni, Giuda and Pietro. They all act for the director who wants to stage the Passion of the Christ. Soon, however, he will have to accept that the story will be told by his characters-four apostles instead of twelve, and a mysterious woman called Kundry-who will tell their own version of the Passion of the Christ. For nearly a year, Lamuraglia

168 From now on the play will be cited as CG. Cristo Gitano was first performed at Teatro Rifredi in Florence on April 24, 2003.

169 A third play, not included in this chapter, is Zingarità (2004).

170 "to give voice and visibility to hidden truths that cannot be visible in another place" (Teatro del Legame, n.d.). Via this link it is also possible to watch a recording of the play: http://www.teatrodellegame.it/cristo-gitano/.

171 The legend is still narrated in some areas of Andalusia, where the statue of Cristo Gitano is carried during a procession (Lamuraglia, 2005, p. 11). Tabucchi wrote Gli zingari e il Rinascimento: Vivere da Rom a Firenze (Tabucchi, 1999), based on his personal experience of the area assigned to a Roma community on the outskirts of Florence. For Tabucchi the city is at once ancient and humanist, intolerant and politically uncompromising. 
and his collaborators regularly visited Olmatello, the Romani community on the outskirts of Florence, where they learned about their traditions and where Lamuraglia met the five Roma who became members of the cast for Cristo Gitano. One acted as Gypsy Christ and four others as characters named after four of the apostles: Giuda, Giacomo, Giovanni and Pietro. The other three characters-the director, his assistant, and Kundry, a female character from the legend-are Italians.

During the Theatre laboratories that ran for a year, they had to face challenges concerning theatrical concepts such as "character" and "theatrical fiction", which were not previously known by the Roma. In the end, it proved to be a very rewarding experience for everyone involved: the director, his collaborators, the Town hall staff and the Romani community. The sheer fact that Romani and Italian families sat next to each other to watch the performance was a major achievement, that shows the revolutionary potential of theatre, as stressed by Lamuraglia: "non solo la sala è stracolma, ma vediamo anche intere famiglie di Rom, con padri, madri, figli, neonati, zii, nonni. Il primo miracolo di Cristo Gitano è già avvenuto. Fiorentini e Rom a sedere accanto, per vivere un'unica esperienza"172 (Lamuraglia, 2005, p. 51).

As a theatre director, Lamuraglia is less interested in revealing the marginality of the Roma than he is in approaching them as a community living on the "border", as a space located furthest from the mainstream or centre. In his article "The Fascination of the Margins", Lamuraglia maintains that "the margins should not be marginalized; conversely, they hold a prominent position for the appreciation of the Centre in its spatial, existential and communal dimension ... the centre and the margin share a relationship of reciprocity in which the one continuously redefines itself starting from the other whose precious presence is guarded and protected” (2013, p. 131). Being fascinated by the marginal other implies a willingness to listen and find similarities even if what is immediately visible is difference. The Roma are regarded as "quintessentially" different because they choose to live according to their culture, even though this means being confined to the margins of Italian society. Lamuraglia says that a "traditional" mind finds it hard to understand Romani culture; for example, their rites are interpreted from the pagan, Jewish and Catholic traditions, on an individual rather than a collective basis; they believe in destiny, they do not have a written history, and their preference for living in extended families has not changed, as it has in the mainstream Western world (Lamuraglia, 2005, p. 26).

The stage performs the important function of providing a space where "the margin" can become visible, being manifested through the voice of members of the Roma community. Theatre is a sacred space for Lamuraglia, the very space where the

172 "We have [a] full house, with Romani families coming into the theatre, mothers, fathers, children, babies, uncles, grandparents. Cristo Gitano has performed its first miracle; Florentines and Romani sit next to each other to share the same experience” (Lamuraglia, 2005, p. 51). 
community and its "other”, the "gipsies" meet and confront each other (Lamuraglia, 2013).

The play begins with four Roma praying in Romaní. From the outset, the Italian audience is placed in an alienating space since the language impedes their participation in the event on-stage. However, an attentive spectator can overcome the linguistic barriers by relating to whatever familiarity they can find, for instance, in the act of praying itself. From the beginning, Lamuraglia wants the audience to relate individually by looking for similarities rather than stopping at differences.

It is evident from the beginning that the five characters' versions of the Stations of the Cross will not be conventional. For the Italian spectators, the play becomes a liminal space where some familiarity with the story, and the unfamiliar, meet. At the first Station of the Cross, Jesus washes the feet of his disciples, whereas in the play, the disciples wash Jesus's feet with wine. At the second Station, Jesus shares bread and wine as symbols of his body and blood, but in Cristo Gitano, Jesus eats the bread and drinks the wine, leaving the disciples astonished. Unlike Jesus, Cristo Gitano does not wish to be known for his words, and he does not believe that his disciples are ready to receive his teachings. Furthermore, he does not want to fulfil his destiny; he would rather bribe Giuda to hide him, and thus avoid being sacrificed for the benefit of humanity. This is the exact opposite to what is narrated in the Bible; Jesus is betrayed by an apostle for thirty dinars, thus fulfilling his Father's will. It is evident that the gypsy Christ is an individual who will not keep his promise to be crucified, even though the four Romani want him to be sacrificed for the benefit of their people as a community. He is the reversal of the biblical Jesus: "Jesus Christ was God and became man"; "Cristo Gitano is a man who becomes God" (Lamuraglia, 2005, pp. 81-82). According to Lamuraglia, the performance had an enriching effect on the Romani actors, who were confronted with new insights to interpret and understand their own myth from a different perspective (Lamuraglia, 2005, p. 9).

Acknowledging that many aspects of Cristo Gitano are the reverse of Christian mythology does not destroy its meaning altogether; on the contrary, it generates new meaning. As an example of theatre at the margins, it does not hesitate to reveal strong differences because this is where similarities begin to be revealed, and this is the point when centre and margin can identify with each other and share the same space. Moreover, where the differences between Gağe (this is the term used by the Roma to define non-Roma) and Roma appear greater, a new awareness may appear, namely the recognition that, beyond different cultural veneers, expression of the sacred through ritual actions is found cross-culturally. As Lamuraglia outlines: "Cristo Gitano ... si è sacrificato, o è stato sacrificato, non sappiamo di chi sia la volontà. Ė il sacrificio per fondare il legame. Questo unisce il cristianesimo al paganesimo, e alla spiritualità dei Rom"173 (2005, p. 45).

173 "It is not known whether Cristo Gitano decided to sacrifice himself or [whether] he was sacrifi- 
Lamuraglia's interpretation of Cristo Gitano also comprises a metatheatrical dimension. As director of the play he questions his choices, their impact on the story's denouement, and the effect on the Romani community in the theatre. This critical thinking is expressed through the character of the director. He has a central role because of his position of power, and when he makes his entrance before the crucifixion, he wants to have control of the play's development, as described by the stage-directions: "Al centro del palcoscenico, prende una sedia e si mette a sedere. I rom in terra sul proscenio" 174 (Lamuraglia, 2005, p. 68). When placed in the position to judge Cristo Gitano, he refuses, as Pilate refused to pronounce judgement on Jesus. As for the Romani characters, both the director and Cristo Gitano represent a means by which to strengthen the cultural bond with their community. However, the director is interested in acting and staging techniques, which are fictional, whereas the Roma want to perform a rite that for them is real and part of their culture. The director remains convinced of his approach to the play, but he decides to step back to allow the Roma to finish the play according to their own cultural knowledge of the myth (Lamuraglia, 2005, p. 43). It is arguable that the decision made by the director-as-character contains some autobiographical elements, because Lamuraglia was committed to the difficult task of mediating between cultural and religious traditions on the one hand, and making difference visible without distancing the audience too much or imposing his perspective on the Roma, on the other. His final choice was to provide guidance without imposing his own view excessively.

Cristo Gitano has succeeded in making a difference because the play has allowed the profane, at the margins, to share the centre with the sacred. In this union, theatre reveals its sacredness. The stage is the space where the margin can meet the centre, actors meet audience, reality meets fiction, and where, according to Lamuraglia: "It is now easier to see the sacred sense of the territory ... and the mental and material setting of a theatrical space. Two universes founded on a mutual agreement inspiring an order of distances, a dialectic between the inside and the outside, and the relationship between Centre and Margins" (Lamuraglia, 2013, p. 130).

The second play, Telerom. La televisione degli zingari ${ }^{175}$ is a parody of well- known Italian television programmes, conducted by Roma from their own perspective. As in Cristo Gitano, adopting the technique of reversal adds another, different point of view that contrasts standard views marginalizing diversity.

ced. It is the notion of 'sacrifice' that provides the connection between Christianity and paganism, and the type of spirituality practised by [the] Romani people” (Lamuraglia, 2005, p. 45).

174 "At the centre of the stage, he grabs a chair and sits down. The actors sit on the floor below him" (Lamuraglia, 2005, p. 68).

175 First performed in April 27th, 2005, at Teatro Cantiere Florida in Florence. The play can be watched via this link: https://www.youtube.com/watch?v=yI8q2_Xfrp4. 
Whilst the ironical news brings laughter, screen projections of Romani life elicit sadness for their living conditions. Whilst the part about television is dramatized, the drama of life is projected on the screen. The sketches in this play are performed by three Roma, whereas the assistants are Italians. Lamuraglia, as director, is an off-stage voice that provides guidance to the actors. In one instance, he includes a metatheatrical component when he openly says that he needs to copy well-known and appealing TV programmes because the Roma themselves do not attract spectators. Contrary to television studios, which are bright and stylish, the news programme TGRom is broadcast from a semi-dark space, with hardly any furniture. TGRom delivers ironical news based on common stereotypes about the Roma. So, for example, the news of a lorry from Eastern Europe carrying horses and a Romani family is read as an ordinary event rather than with the typical alarmism of the Italian newsreaders; the problem of Romani beggars at traffic lights is seen in reversal, since the replacement of lights with roundabouts creates unemployment among the Roma. Moreover, the "Lega Rom" (a parody of the nationalist Northern league party) wants all the inhabitants of the city of Bergamo to leave, because it has now been proved that the Roma inhabited the area long before them. Ironically, there are plans to build a "Bergarom" (a camp for the people of Bergamo) on the outskirts of the city. This use of irony serves to produce estrangement in the spectators; the truthfulness of the news is not challenged, but the altered tone reveals another side to conventional news broadcasts, which largely condemn the presence of Romani people in Italy.

The sketch Il grande Olmatello - cinque anni chiusi in un container ${ }^{176}$ is a parody of the reality show Il Grande Fratello (Big Brother). Parody, in Linda Hutcheson's definition, features a "repetition with critical distance that allows ironic signaling of difference at the very heart of similarity" (1988, p. x). The screening begins with footage of the Olmatello camp outside Florence, with the containers in full view. The camera looks inside a container where four Roma read on a sofa, whilst three children chase each other. The shot reveals the presence of a camera and the filmmaker, who is heard asking the children how long they have been living in the container. The camera zooms in with a close-up of the books, all classics of "Western" philosophy, such as Seneca and Plato. Through parody Lamuraglia raises questions as to what is taken for "natural". It is evident that the brief sketch is artificially constructed with the intention of inviting the spectator to reflect on Romani people reading classics, since the media representation of them has led to the assumption that the Roma cannot be literate, let alone educated. It is impossible to predict the outcome of this on the audience's consciousness and belief system, but the scene can bring to the surface ingrained prejudices and inherited stereotypes towards them.

Moreover, the sketch plays on the relationship between fiction and reality, since Roma actually do live in containers, but while the staging of the play is fictional, $I l$

176 “The great Olmatello - five years stuck in a container”. 
grande Fratello is a reality show which is taken to be real. Playing with the close association between reality and fiction is an invitation to consider that what is considered "real” about Roma can be "imagined” for one's own convenience.

The interplay between fiction and reality is repeated in the second part of the performance. Here an Italian man introduces himself as "the traveller". He makes his first, brief appearance at the beginning of the play, from a dark corner of the stage, where he introduces himself, saying he is there "to repair" by taking the Roma on a journey back home, where their journey began over a thousand years ago. With his second appearance towards the end of the play, he invites the three characters from Telerom to sit down and watch a screening. In the first part of the screening, the three characters are interviewed separately and are allowed to tell their story. The use of theatrical intermediality develops a dialectical relationship between the illusion of the stage and the realism of the filmic image, the fictional characters on-stage and their experience in life. This section is full of realism and offers material for reflection. Their stories tell of families, friends, work, and ordinary lives which were destroyed when the Balkan war broke out and the Romani people were forced to leave. The war forced them to leave and undertake a perilous journey, often as illegal immigrants in Europe, where they have been marginalized by the prejudice against them, denied work and forced to beg and steal to survive, thus reinforcing the negative stereotypes surrounding them.

The final part of the screening features a short film of an epic boat journey, with the five actors travelling from Italy to India. This is accompanied by a poetic commentary on life as a journey which starts with the first breath and ends with the last one. Interspersed with philosophical commentary, the end of the play aims to unite both actors and spectators to a common origin for a common future.

The third play of the trilogy, Zingarita ${ }^{177}$ (2005), reinforces the poetics expressed in the two performances analysed thus far. Zingarità takes inspiration from two classic love stories with Romani characters: Makar Ciudra by Maxim Gorky and Gli Zingari by Alexander Pushkin. Aleko and Zemfira are the protagonists of the first story, Loiko and Radda those of the second. The four characters mirror each other, presenting their similarities to one another in reversal. Aleko has left everything to be with Zemfira, who prefers freedom to being possessed by one person. Loiko loves freedom, whereas Radda is possessive. Only a collective act of death can reconcile the disparity between possession and freedom. This version contrasts with the literary text, in which the death is inflicted by the male characters. The final scene is a tableau, with the four characters positioned to look as if they are all about to stab another and be stabbed in turn. The end is a paradox that does not offer a solution to the dramatic conflict between love and freedom, but gives the spectators the freedom

177 First performed on the 29th of April 2005 in Teatro cantiere Florida, Florence. The play can be watched via this link: https://www.youtube.com/watch?v=tIYei7hUdLO. 
to draw their own conclusions. As stated by Lamuraglia in the introduction to the play, the conflict between possession and freedom is typical of the "Western" world, where individual freedom is practised to the detriment of long-lasting relationships, including the family (2011, pp. 105-106).

In the preface to the play, he says that Spanish and Russian literature, and Western literature in general, have fed our imagination with the description of the gypsy as a nomadic "free spirit", passionate musician and dancer (Lamuraglia, 2011). For this reason, Lamuraglia makes the choice to select only Italian actors, in order to establish the continuity of a Western point of view whilst at the same time being critical of this romanticized stereotype. However, the play resists reproducing and reinforcing the stereotype, by breaking the narrative to avoid the audience's identification with the theme of love. Classical literature constructs a romanticized version of the Roma, who are caught between destiny and the possession of a rebellious spirit.

Lamuraglia's thematization of love in the play is introduced in an epic form, with a group of musicians who also interact with the actors. The two actors, Roberto and Saverio, read out passages from Pushkin and Gorky, but they are unable to decide who should play Loiko and who should play Aleko. One of the musicians, Papini, who is aware that the spectators are waiting, takes the role of 'destiny' and makes the decision for the actors. The musicians interact with the actors on several occasions, making the play a work-in-progress before the spectators, a choice which shows that theatre is fiction. Yet in doing this, he shows that the stage is more real than fictional:

Radda: (grida a Zemfira) Zemfira! Io lo uccido...

Radda: (shouts to Zemfira) Zemfira! I will kill him ...

Zemfira: (grida a Radda) Sì, Radda! Anch'io lo uccido ...

Zemfira: (Shouts to Radda) Yes, Radda! I will kill him too. . .

Musica

[music]

Papini: Stop! Fermi... (finisce la musica) Qui dicono "uccidere" e voi suonate... (ibid., p. 124)

Papini: Stop! Stop!. . . (music stops). They say “kill” and you play music (Lamuraglia, 2011, p. 124).

Interruptions to the flow of the performance indicates a Brechtian technique of distancing, which is intended to discourage excessive involvement of the spectators in the love-story and the character development, and to encourage more intellectual participation, which is necessary in order to understand the relationship between reality and fiction and the illusion which it generates ${ }^{178}$. In doing so, Lamuraglia

178 "Verfremdung" commonly translated as distancing, defamiliarisation and alienation, is an artistic strategy devised by Bertolt Brecht to distance the audience from emotional involvement in the play 
brings together the timeless drama of love with the drama of being a Roma today. Thereby he makes the performance less about the novels and more about the process of staging the play, which incorporates popular contemporary views about gypsies. Anecdotes shared between the Romani and musicians mention "Western" attitudes towards the gypsies who become the scapegoat or locus of people's frustrations; blaming Romani is what the bank customer does who loses all his money through choosing the wrong investment plan. Outside the bank, he realizes that he has lost his wallet and blames a Roma who happens to be nearby: "Uno zingaro mi ha rubato il portafoglio"179 (Lamuraglia, 2011, p. 125). The bank manager comes out and says: "Questi zingari andrebbero cacciati tutti dall'Italia"180 (Lamuraglia, 2011, p. 125). They smile at each other, recognizing one another as members of the same community, and thereby excluding others. Their behavior is an example of ethnocentrism and xenophobia at the same time. Lamuraglia thereby connects classical literature with the Romani people through the use of contemporary anectodes about the experience of being a Roma today. Loiko, being received by two musicians, tells the story of his family, who are nomads but not always by choice, since foreigners are more easily blamed and expelled from a community than a community's indigenous members. The family settled in Pristina, until they were forced out by the Balkan Wars. He tells that, before the Balkan Wars, his people could choose between travelling or staying at home, but after the war this was no longer possible. The question of nomadism indeed remains controversial. On the one hand, our globalized world has led to a sense of being uprooted, such that we speak occasionally of Neo-Nomadism. The October 2019 Condè Nast Traveller issue is entitled “The New Nomad Issue”, showing glamorous pictures of Western families in idyllic places, with semi-naked children who can experience being 'wild', or adults free to journey inwardly and roam the planet, thanks to the digital age and a good internet connection which allows them to work anywhere. On the other hand, the movement of traditional travelers, such as the Roma, or migrants who leave their countries in search for better opportunities elsewhere, is opposed and persecuted. Therefore, more forcefully than the circulation of people, it seems that it is the circulation of capital that makes "nomadism" desirable in the first place.

through reminders to the artificiality of artistic performance. See Meg Mumford (2010).

179 "That gypsy has stolen my wallet!".

180 "These gypsies should be kicked out". 


\subsection{The Experience of Fiorenza Menni and Andrea Mochi Sismondi in a Romani Community in Macedonia: Whose Voices are on Stage?}

Similarly to Lamuraglia, Menni, the founder of Teatrino Clandestino in Bologna, and Mochi Sismondi (then an actor in the same company) devised a performance after personally coming to know the members of a Roma community for an extended period of time. Unlike Lamuraglia, who met the Roma in Italy, Menni and Sismondi chose to travel to Shuto Orizari, a district of Skopje in Macedonia. This is indeed the only district in the world which is governed by Roma, who constitute the majority of the population. Comune spazio problematico ${ }^{181}$ (2008) and Open Option (2009) ${ }^{182}$ are the outcome of the playwrights' long stays in the community, written between 2007 and 2009. Their intention in these compositions was twofold: on the one hand, to explore their own engrained responses towards a people who are too often "translated" through stereotypes and prejudice, and, on the other hand, to explore the uneasiness felt by occupying a position which is socially unconventional, namely as foreigner and minority member, in a Roma community outside Italy. For Teatrino Clandestino the anthropological journey, which is experienced both inwardly and outwardly, is a fundamental component of being an actor. By choosing to work in Shuto Orizari, Menni and Mochi Sismondi became total strangers, an experience which they could not have had in a Roma camp in Italy, where their identities could perpetuate the dichotomy between locals and foreigners, with the locals in the privileged position of insiders looking at outsiders (Menni, personal communication, May 22, 2014).

Menni says that arriving in Shuto Orizari placed them in a position of alterity: "Siamo andati con nostro figlio ... e la sensazione è stata di essere lampeggianti" 183 (Lo Gatto, 2011). In other words, they felt like "outsiders” within a space possessed by "insiders". To be within a Roma borough as "Westerners" entailed being confronted in different ways by the challenges of being part of a community.

"Comune Spazio Problematico" and "Open Option" are the product of a close collaboration between Teatrino Clandestino and the Theatre Roma in Shuto, which is engaged in discussing and confronting various social and political subjects. Stereotypes and prejudice against the Romani, as well as more socio-philosophical topics such as freedom, equality and a better standard of life, were regular subjects of conversation. As Mochi Sismondi writes, "gli spettacoli sono stati messi in scena in Italia per sensibilizzare il pubblico sulla condizione dei Rom, e sulla possibilità di un

181 First performed June 6th 2008 at Città del Teatro, (Cascina, PI). A manuscript was made available but otherwise there is no written text, which explains the absence of page numbers when citing from the play. The play is also available on: https://vimeo.com/43252952.

182 Mochi Sismondi (2012) told the experience in his book, Confini Diamanti. Viaggio ai margini d'Europa, ospiti dei rom.

183 "We were with our son ... we felt as if the spotlight was shining on us" (Lo Gatto, 2011). 
dialogo ... quella dei Rom è una questione emblematica che può aiutarci nell'analisi di alcuni punti critici della 'nostra' realtà, uno su tutti il rapporto che gli italiani stanno istituendo con gli stranieri ... il nostro scopo è quello di tessere un dialogo a sostegno di una visione diversa"184 (Mochi Sismondi, 2012, p. 177). The intention of the performance was to share views to promote a better understanding of the Romani amongst the Italian community, and not to tell the story of the Romani themselves (Menni, personal communication, May 22, 2014).

Comune spazio problematico (Teatrino clandestino, 2012) takes inspiration from a conversation with Kadané, a Romani elder interviewed in Shuto Orizari about topics such as the meaning of life and capitalism. Menni acts as a young Kadané, whilst Mochi Sismondi adopts the role of an anthropologist who talks to her through an interpreter. According to Menni, the decision to keep Kadané out of the performance is motivated by the fact that her presence could be interpreted less as an attempt to dialogue with the Roma and more as a form of folkloristic attraction. This observation may seem controversial, however, Menni echoes Lamuraglia by raising awareness of the representation of gypsies as skilled musicians and dancers. This, undoubtedly, carries a stereotyping effect of gypsies and raises expectations about their role on a stage $^{185}$. The set is minimalist: A gate divides Kadané from an interpreter and a "Westerner" anthopologist interested in her opinion on political and philosophical matters, rather than on their customs.

The language used is a key aspect of the performance. The questions addressed to Kadané are inspired by the German philosopher Matthias Kaufmann. The interviewer addresses Kadané using learned, academic language: "Il principale punto di avvio della mia ricerca è costituito dalla problematica della fondazione della miglior comunità politica possibile, quella che prevede la minor costrizione per l'individuo"186 (Teatrino clandestino, 2012). The anthropologist uses typical academic jargon, which is unsuitable for a conversation with anyone without specialized knowledge, but he seems unable to find a different register that would bring him closer to the social background of the interlocutor. When asked "cosa vuol dire stare bene, essere felici?"187 (Teatrino clandestino, 2012), Kadané replies by speaking about her experience of poverty. What she says is common to anyone in the same position: she describes the sense of being excluded from playing an active role in society, making decisions for herself, and expressing her opinions in her social context. Both Kadané and the

184 "We staged the performances in Italy in order to make the spectators aware of Romani living conditions and to invite dialogue and give visibility to some deeply engrained issues in our society, for instance, our attitude towards 'foreigners' ... Our aim is to build a dialogue that can support an alternative vision” (Mochi Sismondi, 2012, p. 177).

185 This point will be taken up again when mentioning the other performance "Open Option".

186 "My research is centered around finding the best possible community, one that is the least limiting for the individual".

187 "What does it mean for you to feel good and to be happy?". 
anthropologist inhabit a "comune spazio problematico" [a shared, complex space]. In comparative philosophy, this definition refers to a space where different opinions are compared and contrasted, avoiding conflict in the attempt to integrate differences. In the process, those who pose the questions and collect data are also affected by the experience, and are also perhaps transformed ${ }^{188}$. It is very difficult to assess to what extent the subjects involved, both Romani and the two members of Teatrino Clandestino, were 'changed' by the experience. Undoubtedly, the work by Menni and Mochi Sismondi has generated great interest and opened a dialogue with the public and researchers by constrasting the negative stereotypes that feed the "antizingarismo" [anti-gypsy attitudes] in Italy (Mochi Sismondi, 2017).

Furthermore, Menni and Mochi Sismondi were able to make a theatrical version of "comune spazio problematico" only after having experienced it during their stay in Shuto Orizari. This explains why the role of Kadané has been taken by Menni and not by a Roma; Menni spent an extended period of time in close communication and physical proximity with Kadané, developing what can be described as "an experience" of her.

The staged dialogue between Kadané and the intellectually-minded character can be seen as a possible future community, where all citizens are visible and valuable members with equal rights. This ideal community is the common denominator between Kaufmann's philosophy, as expressed by the young intellectual, and Kadané. She cannot improve her living conditions because her people are not allowed to travel freely in the pursuit of better living conditions, thus forcing all future generations to experience the same poverty. Happiness as described by Kadané-“... avere soldi, una casa e un buon lavoro...” [to have money, a house, a good job] (Teatrino clandestino, 2012) - is the wish of people living in poverty everywhere.

Asking Kadané questions and listening to her point of view becomes, in other words, a political gesture. It shows how a fair society ought to behave and what the local government in Shuto Orizari fails to do. Kadané mentions a playground built by a well-meaning multinational company which failed to acknowledge that selling metal is one of the few ways which people can make some money and feed their children. Within a short time the playground was dismantled. This example shows an imbalance between the decision-making of local authority and its powerless inhabitants. However, even the dialogue between Kadané and the intellectual seems unequal from the point of view of Kadané herself, who is aware that the intellectual will be paid for his work, including the interview, whereas her contribution will not be acknowledged. The performance is not seeking a definite answer, or the perfect picture of the ideal society. It is a shared ground, a transcultural process where what truly counts is one's approach towards the other.

188 On Comparative Philosophy, see Maria Donzelli (2006). 
Along with the jargon employed, language also plays an important role in Comune spazio problematico. Mochi Sismondi speaks Italian, but Menni speaks a made-up language, a choice which is motivated by the conscious desire to avoid imitating Romané. In this connection Menni says:

When a stranger speaks, you listen to the music of his language, a music which does not lack emotional power. The meaning is not conveyed through words, but it passes through other ways. Only after comes, as a support, the translation, but first you have been able to sense the emotional quality of another animal that has expressed itself. When the words come to the spectator's ears, with his eyes he can recreate the link with the person who has spoken, he is freer to perceive the signs which originated the meanings that come to him through the translation. (Angelovska, 2012, p. 207)

Menni and the actress who plays the translator both know what concepts will be mentioned, but they choose not to pre-learn a text. In every performance the translator listens carefully to the answers given by Kadané, interpreting the sound and the feeling conveyed, which are based on pre-established concepts. This stage-technique avoids repetition of a text that can lose its vitality, whereas the change of sounds generates a fresh language each time instead of a script. The only critique of an otherwise wholly ethical and political approach is that, unless the public is told that the language heard is not Romaní, they may fail to realize it, believing that it is imitated, and thus miss the deeper philosophical and ethical meaning of using a made-up language.

\subsection{Open Option (2009)}

In "Open Option"189 Menni and Mochi Sismondi continue to explore the philosophical theme of a better, more just community, which functions inclusively towards those members who stand at the periphery of it. In this performance the Romani play a central role, and perhaps in a more radical way than in the case of Lamuraglia. "Comune spazio problematico" seems to be an experiment before staging Open Option, an attempt through the use of a 'non-language' repeated with this second performance. The title of the performance reflects the content of such philosophical dialogues. During a laboratory with the Roma theatre group, mention was made of the experience of living in mobile homes; one of the Roma actors replied that no-one in the Suto community lived on camping sites, but the possibility was not excluded, further adding that it was an "open option", thus reflecting their openness and adaptability concerning the freedom to travel with no fixed territory and borders (Menni,

189 First performed during the international Festival VIE for Contemporary scene, at Teatro Comunale in Carpi (Modena), 16 October 2009. 
personal communication, May 22, 2014). The actors in “Open Options” were Italian and Roma. The Roma actors were members of the Theatre Roma in Suto Orizari who had been invited to Italy to be part of the performance. Menni requested and obtained a temporary visa for them, a process that was contested by the theatre group in a creative and theatrical manner. The programme for the performance was even printed on official documents to request a visa for 'family reunion' for those who are not part of the European community. The choice of a legal document is controversial, as it challenges the power of a nation to include or exclude those who live in their territory, whereas Menni and Sismondi think that it should be everyone's right to decide where to go to improve their living conditions. Thus, the programme displays a formal, bureaucratic language, which stands next to a statement spoken with confidence about the present time, such as in the words: "Siccome abbiamo fatto in modo di trovarci nella posizione di chi parla crediamo che sia necessario tentare di stimolare un pubblico che fa parte di una comunità molto danneggiata a livello di immaginario, quella italiana" ${ }^{190}$ (Menni, personal communication, May 22, 2014).

The spectator is warned that the performance is the product of a community of Italian and Romani actors who disagree with the socio-political system, which keeps discriminating and marginalizing the Roma. Meanwhile, the Roma on-stage act as philosophers by raising questions based on facts; they question to what extent Italians are more literate than them, offering statistics which show that $20 \%$ of the Italian adult population is not entirely able to read. This reversal of roles, where the Romani ask questions and not the Italians, provides a silenced and marginalized community with the power to speak to a community that has always translated them, presenting knowledge and awareness that is normally unchallenged.

There are three languages on-stage at the same time: the Roma actors speak Romani, Menni speaks an invented language, Italian actors translate questions asked in Italian by the public into an invented language, and translate into Italian for them. The presence of Romani actors on-stage makes the issue of the invented language more poignant, as it seems to ask whether it is even possible at all to use the languages we know when we try to find new visions for a more inclusive society. Menni plays the character of Irina, a Romani living in the streets of Bologna, whom Menni and Mochi Sismondi came to know well and helped until she decided to go back to Romania. Irina did not want to be on-stage herself although she took part in the rehearsal. Could the use of the first person "I", used by Menni, be akin to putting oneself in the shoes of the other? I believe that theatre offers the opportunity of empathic embodiment by the actor, who acts as a bridge between the silent other and the citizens present in the theatre. Irina's story of being alone in Italy, dealing with homelessness and poverty, and having her visa denied because of her background,

190 "Since we are in a position to speak, we will do so trying to touch a community with a very damaged imagination, the Italian one”. 
raises serious questions about contemporary Italian and European society. Irina says: "La mia è una situazione senza sviluppo ed è per questo che voglio andare in Europa, ma non riesco ad avere il visto. In questo modo mi viene negato l'ingresso a quella società dei diritti a cui tutti i popoli europei aspirano"191 (personal communication, May 22, 2014). The Roma philosophers share their point of view and remind the audience that they do not support or take part in any war. To have a nation, a national identity to defend, you need to go to have an army and go to war. The solution to the marginalization of the Roma is not building a state for them, as a state cannot guarantee the free movement of people, or inclusion of anyone in its territory. The "open option", is to leave in peace as a community that supports and includes its minorities. As noted by Angelovska: “[B]y critically pointing out to the Roma community's social exclusion in European nation-states, the play enacts a critique of nation-state as - by definition - supporting structural violence against minorities” (Angelovska, 2012, p. 211).

\subsection{Fragments of Voices: Pino Petruzzelli}

Petruzzelli is one of the most well-known and established narrators of Narrative theatre, a theatrical style developed in Italy in the later decades of the $20^{\text {th }}$ century, in which there are no actors or actions, but only the narrator-performer. This means that the narrator, as author of the story, acts it out as well. The stories can be told verbatim from reality, or they can be invented around real events. Narrative theatre is also known as "civic theatre"; its content is rooted in society and the audience is conventionally acknowledged and addressed during the performance ${ }^{192}$. A story comes to life through the voice and body of the actor, usually without stage props to accompany the narration. It is performed both in a conventional theatre and in unconventional spaces, such as a public square or historical buildings, which can attract an audience that normally does not go to a traditional theatre.

Being sensitive to social injustice, Petruzzelli's staged works are centred on a knowledge of, and respect for, people from different backgrounds. Since the late 1980s, he has travelled to distant and disadvantaged areas, such as the Native American reservations in New Mexico, Palestine and Israel. On-stage he narrates what he

191 "In my home town there are no opportunities, this is why I want to come to Europe, but I don't qualify for a VISA. In this way I am denied access to a society that gives people their rights, which is aspired by all European countries". The text of the play has not been published. The quote refers to the version of the play which has been used by the actors to prepare the show and which has been sent via e-mail to the author of the chapter.

192 The books on this subject tend to focus on the works of individual narrator-actors. For an understanding of this theatrical field, see Daniele Biacchessi, Teatro Civile (2010). 
has experienced, with the intention of giving a voice to those who are not heard. He says:

Il teatro che amo è quello in cui il testo nasce da un viaggio fisico. Un viaggio in cui si è coinvolti totalmente e fisicamente ... dove è indispensabile vivere con e come le persone di cui si parlerà. Come li si potrebbe conoscere diversamente? Come si potrebbe rispettare il loro sudore? La mia è una scelta etica che prevede un approccio empatico. Sento forte la necessità di lasciar parlare quelli che, per la maggior parte di noi, non esistono. Quelli che la vita la trascorrono in silenzio. ${ }^{193}$ (Petruzzelli, n.d.)

Non chiamarmi zingaro (2008) is a published collection of encounters with Romani people whom Petruzzelli met in Italy and other European countries. ${ }^{194}$ It is the testimony of a journey undertaken to meet and get to know the 'gypsies' directly, rather than through the usual negative stereotypes about them. The homonymous, staged version is a selection of stories from different perspectives as to age, gender and place. Petruzzelli offers his conversations either in dialogue or as reported speech, weaving the voice of the Roma interlocutor together with his own voice. However, the narrator does not change clothes and speaks in a monotonous voice throughout. He intervenes personally in the narration by reporting factual details that expand on the context of the story. Empathy is felt through pauses or brief comments that punctuate heightened moments in the narrative, thus bringing it to the attention of the spectator.

Each story is narrated in the present, which makes it more vivid and direct before the spectators, implying that, apart from historical events, the experience of the Roma in Italy today follows similar patterns. The story happens in a specific location-Pisa, the German-speaking part of Switzerland, or Saintes Maries de la Mer in France-and the spectator is thereby placed within the frame of objective reality, a detail that adds a journalistic tone to the stories. The main theme of the stories is the "visibility" of the Roma people, which provokes aggressive reactions in the locals. These locals seek to confine the Romani to non-places with their gaze, such that they are removed from

193 "A theatrical text for me is the outcome of a physical journey. I am wholly involved ... for me it is paramount to live with the people I meet and share their lives. How could it be otherwise? How else could I understand them? I make an ethical choice based on an empathic approach. I feel the urge to give a voice to those who are not seen and spend their lives in silence” (Petruzzelli, n.d.).

194 "Non chiamarmi zingaro" was first performed in Teatro Stabile di Genova on July 20, 2009. The last chapter of the book was omitted from the performance and became another researched performance, Zingari: l'olocausto dimenticato, (Gypsies: the forgotten holocaust) to create a memory of the genocide of the Roma in concentration camps, since there has been little mention of them as victims of the Holocaust. It was first performed in Teatro Stabile, Genoa, January 24, 2004. Another version of the performance took the name ,Porrajmos: l'olocausto dimenticato degli zingari‘ (Porrajmos: the forgotten holocaust of the gypsies) and took place in the Risiera di Sabba, a former concentration camp in Trieste, on January 27, 2009. The performance was shown on RAI 3 Friuli, the regional branch of the national broadcaster RAI. 
any form of benefits or facilities that would make them part of a community. A nonplace, as described by Augé, is one with no memories, more akin to a space that is not historical, relational and not concerned with identity (Augé, 1995, pp. 75-77). In a non-place, identity may suffer in isolation. Some Romani choose to become invisible. In one short story, an Italian woman that Petruzzelli met on a Greek island confesses to the narrator that she kept her "gypsy" origin a secret, even from her husband and children, for fear of being prejudiced: "Ho pensato a come sarebbe potuta essere la mia vita se queste origini fossero state visibili”"195 (Petruzzelli, 2008, p. 136) In another short story, Petruzzelli tells of Giuseppe Catter, named “Tarzan”, a partisan who distinguished himself in the fight for the liberation of Italy in World War II, and who is remembered with great honour by General Alexander. In the collective memory, Catter is Italian, but he was a "gypsy". Petruzzelli expresses his comments in a sustained monotone to avoid any possible influence on the spectator, but at the same time inviting them to reflection. He ends Catter's story saying: "Peccato che nessuno

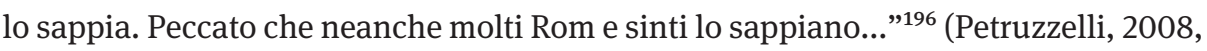
p. 222). By revealing Catter's identity, one may wonder whether the perception of him may change if he is found out not to be "Italian".

When he says that Catter's true identity is not even known by "his own” people, Petruzzelli muses in a long silence about the slow erosion of a people who choose to "die" as a group in order to survive as individuals. At the end of the story of the Italo-gypsy woman, Petruzzelli quotes from a book: “... Alcune isole sono gravate del pesante fardello del passato, che pesa sul loro equilibrio. Quelle che non riescono a iscriversi nel protocollo della costa restano per sempre dissidenti, orfane, solitarie, isolate" ${ }^{197}$ (Petruzzelli, 2008, p. 137). The analogy between islands, as orphans of a "parent land", and the woman's identity, as an "orphan" of her "homeland", may be obvious, yet the metaphor gives the spectator the opportunity to look deeply into its implications. The Roma are not deprived of a homeland because they are nomadic; they still have a collective identity. But it is not the product of national borders; it is a group identity with shared history and traditions. Severing the origin, and thereby denying a belonging, brings on a form of death.

When the gagé-the Roma word for non-Romani-are involved in the narrative, they seem to be indirectly associated with the death of the Romani people. The death of two brothers and their little cousin in a sudden fire that broke out in a gypsy camp in Livorno can be seen as the outcome of a pursuit perpetrated by authorities and locals alike, until the families withdrew to a peripheral area, a non-place, retreating to precarious makeshift accommodation where the children met their death. In another

195 "I thought about how my life would be if my origins were known".

196 "Shame that nobody knows about it. Shame even the Roma and Sinti do not know".

197 "Some islands are burdened with a past that disturbs their equilibrium. Those islands that do not fit into 'parent land' remain orphaned and isolated". 
story told by Doro, who formerly lived in a camp in Opera near Milan, we learn that his father died shortly after their camp was demolished and all their belongings were destroyed by order of the local authority. It was the outcome of months of attacks and illegal sit-ins by right-wing groups who shouted slogans against the Roma. "Non pensavo che qui in Italia saremmo stati trattati come bestie" [I would never have thought that we could be treated like animals in Italy], says Doro (Petruzzelli, 2008, p. 27).

The story of the Swiss writer Mariella Mehr and her people, which ends the performance, is also about death. Mehr is of Yenish origin. The Yenish, an itinerant group found primarily in some Northern European countries, are not Roma, although, like the Roma, they do not have a nationality, are itinerant and have long experienced persecution and social marginalization. It is because of these similarities that Petruzzelli decided to include Mehr's story in the performance. Although not specifically mentioned, the implementation of a project founded by Alfred Siegfried-to transform the Yenish People from nomadic to nationalized-with the permanent loss of a collective identity and with individual identities scarred and mutilated by losses and separation, can be equated with "death". The project involved eugenics and removing all the children from their families. Mehr is a victim of the project twice over; as a child she was taken away from her family and placed in an institution, while as a young woman she had her newborn baby taken away for adoption by a Swiss family. Just as the Italo-gypsy woman did, these children and adults have become islands without a homeland.

Petruzzelli's narration fulfils two important functions. On the one hand, it gives the stories a deeply human dimension, since news about the destruction of gypsy camps and evicted gypsies never portray the human aspect of these events. When Petruzzelli tells their stories, he mentions their feelings, their sense of loss and sadness, their pain of not being seen as other human beings. On the other hand, through mentioning events like the Swiss Project, which is perhaps still unknown by today's spectators, he preserves the memory of socio-historical persecution towards minority groups, and denounces the absence of a sense of humanity towards them.

In conclusion, the transcultural approach that features in this chapter consists primarily in the playwrights' intentions to get to know the Roma personally. This is the beginning of a mutual exchange of listening and speaking, in which even the voice from the margins can be heard. The significance of a physical journey undertaken to meet the Roma in their own environment "de-centers" them from a privileged "majority" position and symbolically challenges the binary opposition of centre/margin which remains alive in Italy today. The theatrical works adopt different approaches to place the voice of the Roma at centre stage for the attention of the spectators, with distinct, and sometimes similar, outcomes. Lamuraglia, Menni and Mochi Sismondi, and Petruzzelli, challenge traditional views on the use of a cultural space which is traditionally managed by norms that are apt to please the majority. Lamuraglia's use 
of irony, parody and the theatrical techniques of distancing to de-construct conventional views on the Roma reveal engrained habits of speaking of the Roma always in terms of how their presence negatively affects the majority. The use of irony allows the inverse result, with the Roma expressing their concerns at the way that the majority has negatively affected them. Lamuraglia also draws cultural similarities between Italians and the Romani thanks to his role as a cultural mediator. Staging religious beliefs means that differences are highlighted in the way that cultures conceptualize and regard the sacred, revealing that there are intrinsic similarities between the need of different peoples to ritualize and perform the sacred as a means of connecting community members together.

Similarities are also at the heart of the philosophical approach adopted by Menni and Mochi Sismondi, for whom the question of giving a voice to the Roma deeply shapes their theatrical approach. Giving a voice and revealing similarities go hand in hand. The Roma are not given an opportunity to express an opinion about living in the contemporary world. Therefore, Menni and Mochi Sismondi reveal that the issues the Roma have to face, such as poverty, being happy and having a job, and the feelings associated with them, are not dissimilar from the feelings of mainstream society. By adopting a transcultural approach based on equal sharing in dialogue, hearing multiple voices becomes a political act of social inclusion and emancipation. The new concept which Menni and Mochi Sismondi seem to suggest needs a different language to bring it to life. The process to carry out a performance is also a political act; inviting Romani actors to Italy is viewed as an opportunity to critically compare the Romanis' pacifist beliefs within a community without borders with a nation-based culture which is defended through conflict, such as is adopted across the "Western" world. Petruzzelli's gentle response contrasts with the aggressive responses manifested against gypsies. On-stage, he lends his voice to the Roma who told him their stories of painful exclusion, which forced them to live outside communities, or in some cases, to be completely removed and isolated from the family, as in Mehr's story. His narration reminds us that oppressive practices cause great pain. The Roma suffer greatly the effects of social exclusion, yet their pain is never considered when they are mentioned by media and authorities. Conventionally, loss is only mentioned when the majority complaints about the loss of safety and space when the Roma move in to their territories. The monologues show loss from the perspectives of the Roma, where it means the loss of lives, homes, communities, and both individual and communal identity. By speaking of their emotions, Petruzzelli gives them the humanity which is taken away by traditional attitudes towards them. It is a political act that denounces the dark side of civilized Italy and Europe at large.

The journey undertaken by the playwrights includes the "self", who have become "other", and the "minority", in order to hear voices which were previously unheard. By moving away from standard practices of the theatre, Lamuraglia, Menni and Mochi Sismondi and Petruzzelli all individually create a life-world that can open up other 
life-worlds, in the form of other new experiences that may generate new realities for both the Romani people and the spectators.

\section{References}

Ahmed, S., Castaneda, C., Fortie, A.-M. (2003). Uprootings/Regroundings. Questions of Home and Migration. Berg Publishers.

Angelovska, D. (2012). Open Option: Roma, Discrimination and Peace Building in Macedonian Šuto Orizari. In O. Simić \& Z. Volčić (Eds.), Peace, Psychology in the Balkans: Dealing with a Violent Past While Building Peace (pp. 199-214). Springer.

Ashcroft, B. \& Griffiths, G. (Eds.). (2013). Postcolonial Studies: The Key Concepts. Routledge.

Augé, M. (1995). Non-Places. Introduction to an Anthropology of Supermodernity. Translated by John Howe. Verso.

Aull Davies, C. (2002). Reflexive Ethnograpgy. A guide to Researching Selves and Others. Routledge. Biacchessi, D. (2010). Teatro Civile. Nei luoghi della narrazione e dell'inchiesta. Verdenero.

Condé Nast Traveller. October 2019. Retrieved April 4, 2020, from https://www.cntraveller.com/ gallery/12-reasons to-buy-the-october-2019-issue-of-conde-nast-traveller

De Martino, A., Puppa, P., Toninato, P. (Eds.). (2013). Differences on Stage. Cambridge Scholars Publishings.

Donzelli, M. (Ed.). (2006). Comparatismi e filosofia, Quaderni del dip. di Filosofia politica. Università L'Orientale. Liguori editore.

Glissant, É. (1996). Introduction à une Poétique du Divers. Gallimard.

Hutcheson, L. (1988). A Poetics of Postmodernism. Routledge.

Lamuraglia, D (2005). Il Libro di Cristo Gitano. Pagnini Editore.

Lamuraglia, D. (2011). Opere Teatrali. A\&B editrice.

Lamuraglia, D. (2013). The Fascination of the Margins. In Differences on Stage A. De Martino,, A., Puppa, P., Toninato, P. (Eds.), Differences on Stage (pp.128-144). Cambridge Scholars Publishing.

Lo, J. \& Gilbert, H. (2002). Towards a Topography of Cross-cultural Theatre Praxis. Mit press, 46(3), 31-53.

Lo Gatto, S. (2011, May 18). Civile e problematico: è lo spazio di Teatrino Clandestino. Retrieved March 3, 2019, from http://www.klpteatro.it/teatrino-clandestino-civile-spazio-problematico Loomba, A. (2005). Colonialism/Postcolonialism. Routledge.

Lucassen, L., Willems, W. H., \& Cottaar, A. (1998). Gypsies And Other Itinerant Groups. A SocioHistorical Approach. Palgrave Macmillan.

Mochi Sismondi, A. (2012). Confini Diamanti. Viaggio ai margini d'Europa, ospiti dei rom. Ombre Corte.

Mochi Sismondi, A. (2017) "Linguaggio teatrale, dispositivi narrativi e anti-zingarismo" in Anuac, 6(1), 187-208.

Mumford, M. (2010). Bertolt Brecht. Routledge.

Ortiz, F. (1947). Cuban Counterpoint: Tobacco and Sugar. A. A. Knopf.

Pavis, P. (1996). The Intercultural Performance Reader. Routledge.

Petruzzelli, P. (2008). Non Chiamarmi Zingaro. Chiarelettere.

Petruzzelli, P. (n.d.). Viaggi. Retrieved October 25, 2019, from www.teatroipotesi.org/viaggi.html

Rame, S. (2018, January 11). Migranti, Salvini: "Se vinco riempio gli aerei e li riporto a casa". Il Giornale. http://www.ilgiornale.it/news/politica/migranti-salvini-se-vinco-riempio-aerei-e-liriporto-casa-1482213.html 
Tabucchi, A. (1999). Gli zingari e il Rinascimento. Vivere da Rom a Firenze. Feltrinelli. Taylor, D. (1991). Transculturating Transculturation. Performing Arts Journal, 13(2), 90-104. Teatrino clandestino. (2012, June 1). Comune Spazio Problematico [Video]. Vimeo. https://vimeo. com/43252952

Teatro del Legame. (2013, November 4). ZINGARITA' (del legame, dal legame) - testo e regia di Daniele Lamuraglia [Video]. YouTube. https://www.youtube.com/watch?v=tlYei7hUdL0 Teatro del Legame. (2014, December 31). TELEROM la televisione degli zingari - testo e regia di Daniele Lamuraglia [Video]. YouTube. https://www.youtube.com/watch?v=yl8q2_Xfrp4 Teatro del Legame. (n.d.). Teatro del Legame presenta CRISTO GITANO regia di Daniele Lamuraglia. Retrieved March 20, 2020, from http://www.teatrodellegame.it/cristo-gitano Toninato, P. (2014). Romani Writing: Literary, Literature and Identity Politics. Routledge. Young, J. C. R. (2001). Postcolonialism: An Historical Introduction. Wiley-Blackwell. 